\title{
Electronic Banking and Customer Satisfaction in Imo State (A Study of Selected Commercial Banks in Imo State)
}

\author{
Chimaobi Ijeoma, Jane Chinyere Akujor and JacinthaChikamnele Mbah
}

\begin{abstract}
This study was carried out to examine the impact of electronic banking on customer satisfaction in commercial banks in Imo State. The aim is to determine the relationship between electronic banking and customer satisfaction in some commercial banks in Imo State. The study used primary data; the instrument used in gathering the primary data was questionnaire. The statistical tool of analysis is the Pearson Product Moment Correlation Techniques. The result revealed that there is positive relationship between electronic banking and customer satisfaction in United Bank for Africa Plc, Access Bank Ltd and Keystone Bank Ltd. It also revealed that there is positive relationship between Automated Teller Machine and Mobile Banking and customer satisfaction in United Bank for Africa Plc, Access Bank Ltd and Keystone Bank Ltd. More so, the study shows that there is a negative relationship between point of sale and customer satisfaction in the three (3) banks. This implies that increase in charge levied on those electronic banking systems will have a corresponding decrease in customer satisfaction and vice-versa. The study therefore recommends the following; that banks should improve continuously in the advance of Automated Teller Machine for speedy transaction when using by customers; financial institutions (banks) and nonfinancial institutions should endeavor to make available POS machine at a minimal cost to some small business outlets in order to help in the achievement of cashless economy; the banks should ensure that there is creation of more internet security in internet and mobile banking so as to avoid loss of cash by customers as a result of fraudulent activities and finally, continuous advancement and reengineering information communication technology should play a vital role in the overall synergy of financial institution operations (banking). It becomes more important for bank leadership to deepen investment in ICT products to increase speedy, user friendly and perfect services. These will make Nigerian banks to stand firm in terms of efficiency, profitability, reliability, and competitiveness among its global competitors and to withstand challenges and changes that may occur in ICT controlled globalized economy.
\end{abstract}

Index Terms - Electronic banking, Customer Satisfaction, Point of Sales, Automated Teller Machine, Mobile Banking.

\section{INTRODUCTION}

Today, the banking industry has moved into an era of technology which is driven by sophisticated innovations in ICT. The industry shares the common attributes of hightechnology industry, most notably: market uncertainty, technology uncertainty and competitive volatility.

Published on November 28, 2020.

Chimaobi Ijeoma, Michael Okpara University of Agriculture, Nigeria. (corresponding e-mail: ijeomachimaobi68@gmail.com)

Jane Chinyere Akujor, Federal University of Technology Owerri, Nigeria.

Jacintha Chikamnele Mbah, Federal Polytechnic Nekede, Nigeria.
E-banking in the $21^{\text {st }}$ century has become widespread and its effect inevitable. An outstanding development in the industry is the adaption of information and communication technologies (ICT) in providing banking goods and services. Examples of ICT-based products include automated teller machine (ATMs) transactions, point of sale (POS) system, mobile banking system and internet banking system.

Before the existence of E-banking, transaction of businesses in the financial and productive sectors had been a difficult and stressful one. Mostly, banks make use of ledgers, folio numbers, and postcards like data sheet where customers name, specimen signature, photo where kept in record. The manual operations caused very slow and inefficient performance of the banks in Nigeria. Technology has affected the performances of all Nigerian banks in the previous time. This century has been associated with the availability of dynamic customers whose interest is targeted on banking services, improved regulation, and high profitability.

The Electronic means of payment is a way of carrying out financial transactions with the use of mobile or internet in order to reduce the huge risk involve in carrying physical cash or paper cheque. Electronic banking guarantee speed, efficiency, fair and well secured transactions compared to that of cash-at-hand procedure [20].

E-banking means of payment was adopted in Nigeria as a result of the massive volume and huge amount worth of transactions carried out with the use of ATM, POS, And Mobile phones etc.

In some cities in Nigeria and financial parastatals, Electronic banking services are more effective and profits oriented and have gained a lot of grounds as the customers recognized and accepted them as a solution and remedy to the problems of poor quality services similar to the Nation's banking system. However, what is hidden is the extent to which electronic banking services have coiled down the stress or problems related to banking and promote customers' satisfaction [29].

More so in some states like Imo state, banking organizations have promoted electronic banking for its usefulness to its customers. However, the level of utilization seems poor and ineffective which was evidential to the lengthy queues in some bank branches. Low availability of POS in supermarkets, some governmental and private organizations still prefer paying cash at revenue points evidenced in urban centers in Nigeria [8].

This study is carried out based on the problems associated with electronic banking and customer satisfaction and it tends to provide a lasting solution to the major problems faced by customers in utilizing the benefit of electronic banking. The first problem is the issue of constant damage in the system and unpredictable internet failure. This has unconstructively 
impinged on banks' maneuver and influence their efficiency and productivity.

Similarly, banks are habitually faced with system inefficiency due to rise in technical changes resulting to accumulated costs hence leading to low productivity.

Secondly, the issue of insecurity and absence of privacy have led to more problems to electronic banking system in banking sectors and finally, the operation of hackers which is another problem instigating the banks from achieving the full benefits presented by electronic banking.

These problems can lead to financial and capital losses due to erroneous means of transactions, data privacy and confidentiality, unauthorized access or infringement to financial institution systems and transaction, which will in turn, cause them heavy losses on their profitability and general performance of the system.

Hence, this research will tend to look at the causes of these problems and profound likely solutions of electronic banking issues viz-a-viz customers' satisfaction.

The general intent of this study is to examine the impact of electronic banking on customer satisfaction in Nigeria. The specific objectives therefore include:

1. To analyze the effect of automated teller machine (ATMs) on the customer satisfaction.

2. To examine the effect of point of sales (POS) on the customer satisfaction.

3. To investigate the effect of mobile banking system on the customer satisfaction.

\section{CONCEPT OF EleCtRONIC BANKING}

Electronic banking is financial institution device which gives banking clients an edge to carry out banking transactions, either through financial or non-financial banks website. The innovations in technology revolution give birth to more sophisticated instruments which help and assist the easier way in operating with financial institutions in modern days without going to the banking premises. E-banking services should be structured on the basis of the needs, expectations, wants and experience of the clients according the following standards; firstly, electronic banking services should be user friendly to the banking customers, secondly, electronic banking services should be highly speedy in processing customer's command and finally, there should be a high level of credibility, compatibility between electronic banking services and other technical service.

Electronic banking is defined as a form of financial banking system that operates fund transfer through electronic means rather than physical transfer of cash (hand-to-hand), cheque and other financial relevant documents. Transferring of funds occur between financial institutions such as bank to bank, banks to credit unions and other institutions that perform financial transactions through electronic media. However, cash withdrawal occurs through Automated Teller System (ATM) or pay credit card through a designated personnel or bank with the help of electronic device which facilitates the movement of cash without the presence of both parties in the exchange. Electronic banking depends solely on a computer system that communicates using telephone lines. These computer systems take to record all transfers and ownership of funds and control the activities of both the customer and the institutions in the cash movement. It uses a unique means of identification (access code) to enable each individual access and be more confident in operating electronic means of fund transfer. Its essence is to secure the confidence and ensure the safety ways of using technological (electronic) means in carrying out financial transactions within financial and non-financial institutions and thereby reduces the risk of carrying cash about.

Electronic banking system as the technological innovative service delivery system that offers varieties of financial services like cash deposit payment of utility, cash transfer, cash withdrawal, cash borrowing, cheque and pass book request, account statement request and other necessary financial enquiries [23].

Electronic banking system is defined as a process by which financial institutions (banks) through a platform deliver information and financial services to their clients or customers [12]. Such platform can be through mobile phones, desktop software, telephone, or digital television. E-banking describes more on the uses of ICT and electronic device by a bank to conduct all financial transactions and have interactions within the stakeholders [1].

Reference [26] opined that supply of electronic banking services enables financial institutions (banks) to create and broaden their relationship between their customers and stakeholders. There are other numerous benefits which bank may drive while using electronic banking. Such benefits are as follow: customer's confident, market segmentation, creativity in terms of product and service delivery, more efficient marketing, and communication at lower fee.

\section{RECENT TRENDS IN ELECTRONIC BANKING}

The adaptation of information and communication technology in banking system has made financial institutions more sophisticated in carrying out financial transactions on or on-behalf of their client. The introduction of innovation in banking system has eradicated the cost of maintaining physical presence structures like traditional banks do. Electronic banking has increased the interest rate on service account and customers through internet can carry out all the financial transactions they wish to do without being presence or visiting the banking hall. Such transactions could be transfer of cash from one customer's bank to another, cancellation of financial dealings, enquiring of cash balance and blocking of any suspicious transactions.

Online banking has enabled customers get paid from their employers through automated ways in which such funds goes directly into their accounts rather than the traditional method of payment of cash to hand or cash to bank. Online banking became possible through some devices; ATM (Automated Teller Machine), POS (Point of Sales), internet banking, mobile banking, and other electronic means of cash transfers. 


\section{ELECTRONIC BANKING AND CASHLESS POLICY IN NIGERIA}

The existence of cashless policy does not necessarily mean absence of cash in the economy but introduces system of payment that occurs without the person being present at the point of transaction or carrying of physical cash from one person to another. Consequence of electronic banking is the seamless flow of cash from one sector of the economy to another.

Cashless economy is defined as an economy where deposit cards, credit cards, charge cards and direct transfer are used for making purchases. He also went further to put benefits of cashless economy as reduction of money laundries, risk of losing your cash as a result of robbery and other natural disasters [13]. The introduction and implementation of Single Treasury Account (TSA) in 2015 where the funds of various ministries, departments and agencies of government which previously held account in deposit money bank where transferred to a single remitta system maintained by Central Bank of Nigeria (CBN). The Single Treasury Account has helped in combing all the financial fraud been penetrated in public offices and agencies of the country. Electronic banking has formed the bed-rock of cashless policy through the implementation of electronic payment. Base on that, cashless economy is achieved.

Example of these electronic payment devices include: Automated Teller Machine (ATM), Point of Sale (POS), internet banking, mobile banking, and other means of epayment system. All these media are efficient means which are employed and thereby improve cashless state in the economy.

Central Bank of Nigeria (CBN) has established a new policy on cashless base transactions which says a cash handling charge on daily cash withdrawals or cash deposit that exceeds $\$ 500,000$ for individuals and $\mathrm{N} 300,000$ for corporate bodies. This new established policy on cash base transaction in banks tends to reduce physical carriage of cash around the economy and promote the uses of electronic base transaction system. In one of editorial interview of Daily Sun to the head of Shared Service CBN, Mr. ChidiUmeano on $13^{\text {th }}$ July, 2013 said that cashless policy of CBN didn't contradict the physical carriage of cash by individual but if they must carry cash, they should be able to pay for the charge. He then argued that such economic policy will encourage the reduction in financial crime and reduce high volume of cash in circulation and it is necessary for us to promote and encourage e-banking system by discouraging any means that defiles it. E-commerce can go a long way to provide for Nigeria the platform it needed to attain the vision 2020. According to Central Bank of Nigeria, the cashless policy was established for major key reasons which include driving development and modernization of our payment system in line with Nigerians vision 2020 goal for being among the top economy by year 2020. The charges took effect from March 30, 2012 in Lagos, October 1, 2013 in Rivers, Aba, Anambra, Ogun, Kano and FCT. CBN has announced that charges on cash deposit above N500, 000 will be implemented nationwide with effect from Wednesday April 1, 2020. This comes as an additional charge to the already existing charges on withdrawals. This simply means that whenever a depositor deposits or withdrew cash above N500,000 at any bank branch nationwide (Nigeria), a processing charge fee will be collected from the depositor as detailed below:

\begin{tabular}{cccc}
\multicolumn{4}{c}{ TABLE I: PROCESSING CHARGE FEE } \\
\hline $\begin{array}{c}\text { Account } \\
\text { Type }\end{array}$ & $\begin{array}{c}\text { Withdrawal/Lod } \\
\text { gment Limit }\end{array}$ & $\begin{array}{c}\text { Processing Fee } \\
\text { for Withdrawal }\end{array}$ & $\begin{array}{c}\text { Processing } \\
\text { Fees for } \\
\text { Lodgment }\end{array}$ \\
\hline $\begin{array}{c}\text { Individual } \\
\text { Corporate }\end{array}$ & $\begin{array}{c}\text { Above 500,000 } \\
\text { Above 300,000 }\end{array}$ & $3 \%$ & $2 \%$ \\
\hline
\end{tabular}

Source: GTBank.

An effective and modern payment system is positively correlated with economic development and it is one of the keys that enable the economy to grow. To reduce the cost of banking services (including cost of credit) and drive financial inclusion by providing more efficient and effective financial options and greater reach to enhance the effectiveness of monetary policy in managing inflation and driven economic growth.

In addition, cashless policy tends to comb some negative consequences related with the high usage of physical cash in the economy, including high cost of cash, high risk of using cash, high subsidy, informal economy and inefficiency and corruption [10].

\section{TYPES OF ELECTRONIC BANKING}

For the purpose of this work, the following e-banking devices will be discussed; Automated Teller Machine (ATM), Mobile Transfer, Point of Sales (POS) and Internet Banking.

\section{A. Automated Teller Machine (ATM)}

Nigeria became one of the countries that have adopted the use of Automated Teller Machine (ATM) as a means of cash transfers, cash withdrawals and other relevant cash transactions. It has increased the cash base of banks and the profitability level, making the banking industries more efficient in carrying out financial activities, that is making cash available at all times to enable bank customers have access to cash even at non- banking hours. ATM has also helped in achieving cashless economy being proposed by CBN. It is also a device which carries out financial operations such as cash transfers, cash withdrawals, sale of recharge cards without being present in the banking hall and it can be accessed 24hours/7days [14].

Automated Teller Machine uses network in carrying out some operations such as: cash transfers, cash withdrawals, payment of utility bills etc [32]. Moreover, ATM began operation in most Nigerian banks in the year 2003 with five ATMs from United Bank for Africa (UBA) and First Bank of Nigeria (FBN).

\section{B. Internet Banking}

Internet banking as one of the devices of e-banking is where bank customers can perform all the financial activities on a secured website operated by a particular financial institution which can be a retail or virtual bank, credit union or society. It can also be referred to any financial transactions which are related to online usage. It becomes more necessary 
for banks to increase operating websites through which customers can carry out mostly if not all financial transactions without being present in the banking hall and make some vital enquiries such as; account balance, interest rate, exchange rate and lending rates. Unfortunately, data on internet banking are scarce and it forms a constraint to many researchers in developing an ideal way of improving internet banking [28].

\section{Point of Sale (POS)}

Point of Sale is one of the devices of e-banking which is mostly used as a means of payment of purchases, cash transfers, and cash withdrawals and cash deposits. POS has helped in achieving the cashless economy as intended by $\mathrm{CBN}$ because people now see no reason of carrying cash to the point of purchase. 'Checkout' refers to a POS terminal or the equivalent of an electronic cash register. The device system allows the creation and printing out of receipt which serves as evidence of operation to the operator and his client. In more recent time, investment in a POS system has proven to be vital and source of livelihood to individuals in the country. POS system serves as a means of sales record for businesses and tax purposes [25].

\section{Mobile Banking}

Mobile banking is used in carrying out financial transactions as a result of its availability to a common man. Most bank customers find it easier and reliable using mobile banking in carrying out their financial dealings at their comfort zone without visiting the banking hall. Creation of smartphones has been of help in achieving this and in turn making the economy cashless in the sense that people move about with their mobile phones and find it more reliable in carrying out financial transactions such as cash transfers, payment of utility bills, purchase of recharge cards, obtaining loans, checking balance and making financial enquiries which includes loan status, loan eligibilities etc.

Mobile devices such as mobile phone or Personal Digital Assistant (PDA) are instruments for mobile banking. The initial mobile banking services were offered over SMS, a service known as SMS banking. Globally, mobile banking is used in carrying out financial transactions with little or no infrastructure more especially in remote and rural areas. Mobile banking offer services which includes facility to conduct bank, stock market transaction, to administer account and to access customized information [31].

\section{CUSTOMER SATISFACTION}

Customer satisfaction leverage on the expectations and insight about the services offered. The satisfaction idea leverages on the numerous psychological and physical components. Electronic services have provided benefits for customer satisfaction in dealing with financial institutions with the number of services rendered to their customers. Customers find it very easy and satisfactory in operating in modern banking these days because most of the activities done are at their own convenient which has ended the era of queue system in the banking hall.
Satisfaction is defined as the overall customer approach towards service rendered or an emotional response to the differences between what customer expected and what is being offered, regarding the accomplishment of some need, goal, or desire [17].

Customer satisfaction can also be defined as a verdict following consumption knowledge about the particular service being rendered if it meets its expectation to the customer [24].He describes Satisfaction as an individual perception of enjoyment and dissatisfaction resulting from comparing a product or services apparent performance in relation to his or her expectations [21].

Satisfaction can be related with feelings which an individual derived from a particular product or service in a particular time. Most research affirms that the evidence of pre-consumption expectation is the factor of satisfaction. This explains that a customer has earlier stated the rate of performance of a product before consumption. In terms of consumption, customers' knowledge of the product helps in comparing its expected product performance level while judgment is drawn based on satisfaction comparison.

\section{THEORETICAL FRAMEWORK}

This research is anchored on innovation diffusion theory postulated by [26]. He argues that people's aim to employ technology as a modality to perform a traditional activity. The crucial factor that determine the espousal of an innovation at the general level is as followed complexity, compatibility, relative advantage, trainability, and observability. Good number of banks has taken advantage of information communication technology in their operation in order to improve the standard of its operation. This recent innovation is being achieved through massive development of websites and mobile applications that befits the bank customers' needs. Customers are avail the opportunity to have access to bank operations in anywhere they go as long as there is the availability of the internet connectivity.

This theory is concerned with the way in which a new technological idea, artifact or techniques or new use of an old one, migrates from creation to use. According to IDT, technological innovation is being communicated through a particular medium on time basis among the relative social system.

Technological innovation passes through stages which includes: experience (expose to its existence and understanding its function); affiliation (the forming of favourable attitude to it); decision (engagement to its adoption); implementation (putting it to use); and confirmation (reinforcement base on positive outcome of it).

So many modifications have been put forward to check internet banking threat and fraud. Most users include learned class, people with high society status; more open to both mass media and inter-personal medium for communication and have more contacts with change agents. Mass media medium are relatively more vital at the experience stage, whereas inter-personal medium is relatively more vital at the persuasion stage. Innovation decisions might be optional (where individual or institutions has a real opportunity to 
accept or reject an idea) or authority based (where decision is being imposed by another individual or institutions which possess the necessary power, status or technical expertise). Reference [7] recommend to managers the need for understanding a certain capacity of any technology and what it tends to offer and ensure its use is considered with their operations as well as understands relatively costs and constraints of operating that technology. He also counsels that the general issues to be considered as a volume and variety of results that the technology can achieve which can fit the existing technology use within the organization and the level of its maturity. Internet banking highly relied on the information communication technology since most of its operation is being done on the internet. Customers can interface with their account freely without being present in the banking hall.

\section{EMPIRICAL REVIEW}

Several researchers have investigated the relationship between electronic banking and customer satisfaction in Nigerian banking system. This has generated both positive and negative arguments in the literature. Some of these researches conducted from different part of the world including Nigeria are reviewed below:

Reference [5] examined the impact of Electronic Banking on customer service delivery in the Malaysian Banking Industry: Using Kano's Model. The study adopted Structural Equation Modeling as a tool and instrument for data analysis. The study revealed that there is the existence of relationship between electronic banking, customer behavior and customer service delivery. The findings of the study also revealed a strong argument in the literature review.

Reference [19], studied The Impact of E-Banking service quality on Customer Satisfaction: Evidence from the Lebanese Banking Sector. The study uses primary data which were gathered through survey instrument and adopted structural modeling, SPSS, and Amos in the data analysis. The findings revealed that reliability; efficiency; user friendly; responsiveness and communication; and security and privacy all have a significant impact on customer satisfaction.

Reference [15], carried out a research on E-banking services impact and customer satisfaction in selected bank branches in Ibadan metropolis, Oyo state, Nigeria. The study adopted crosses sectional survey design and sampling Techniques as its methodology. The study used Pearson correlation as the mode of analysis. The findings showed that utilization of electronic banking products (ATM (98\%), internet banking (85\%), electronic transfer (97\%). Constraints experienced include internet network failure, bank fraud and business loss due to failed e-transactions. Customers were satisfied with e-banking due to its cashless nature, cash accessibility, saves time from bank visitation and seamless transactions.

Reference [18] studied The Impact of Electronic Banking Technology on Customers' Satisfaction and Economic Growth in Nigeria. The researchers used statistical parametric test called Pair Sample t-test through the application of SPSS statistical package to carry out its analysis. The findings revealed that there is a positive significant relationship that exists between e-banking technology, customers' satisfaction, and economic growth in Nigeria.

Reference [28] examined the Effect of Electronic Banking on Customer Satisfaction in Selected Commercial Banks, Kenya. The study employed descriptive research design, sampling techniques and structural questionnaire and uses simple regression as its mode of analysis. The result showed that internet banking, automated teller machine and mobile banking prove to have satisfied the customers and was user friendly when using.

\section{RESEARCH METHOD}

The study employed descriptive correlation survey method to explore the relationship between electronic banking and customer satisfaction in keystone bank Ltd,United Bank for Africa plc and Access Bank plc. The purpose of this research design is to contribute to existing literature. The study population comprises of customers of Keystone Bank Ltd, United Bank for Africa Plc and Access Bank Plc and total population under study is 180 customers or respondents of Keystone Bank Ltd, United Bank for Africa Plc and Access Bank Plc.

Judgmental non-probability sampling technique was adopted in the survey. This method allowed the researchers to use intuitive or discretion in selecting the customer that represent the whole population. Copies of the questionnaire were administered to the staff and customers of the respective banks and the participants were placed on an objective response in each statement in five-point likert-scale .Out of 180 questionnaires administered to the participants, only 150 were filled and returned from each respective bank while the remaining 30 were not returned.

The tables below summarize the questionnaire administered and returned. The study hypotheses were tested and analyzed using Pearson Product Moment correction techniques to generate study result.

TABLE II: SUMMARY OF QUESTIONNAIRE ADMINISTERED AND RETURNED

\begin{tabular}{ccc}
\hline $\begin{array}{c}\text { Questionnaire } \\
\text { Administered }\end{array}$ & $\begin{array}{c}\text { Number } \\
\text { Questionnaire }\end{array}$ & $\begin{array}{c}\% \text { of Questionnaire not } \\
\text { Returned }\end{array}$ \\
\hline $\begin{array}{c}\text { Number of } \\
\text { Questionnaire Returned } \\
\text { Questionnaire not } \\
\text { Returned } \\
\text { Total }\end{array}$ & 150 & 83.33 \\
& 30 & 16.67 \\
\end{tabular}

Source: Field Survey, 2020.

TABLE III: SUMMARY OF QUESTIONNAIRE ADMINISTERED AND RETURNED FROM KEYSTONE BANK LTD

\begin{tabular}{ccc}
\hline $\begin{array}{c}\text { Questionnaire } \\
\text { Administered }\end{array}$ & $\begin{array}{c}\text { Number } \\
\text { Questionnaire }\end{array}$ & $\begin{array}{c}\text { \% of Questionnaire not } \\
\text { Returned }\end{array}$ \\
\hline $\begin{array}{c}\text { Number of } \\
\text { Questionnaire Returned } \\
\text { Questionnaire not } \\
\text { Returned }\end{array}$ & 55 & 91.67 \\
Total & 5 & 8.33 \\
\hline
\end{tabular}

Source: Field Survey, 2020. 
TABLE IV: SUMMARY OF QUESTIONNAIRE ADMINISTERED AND RETURNED FROM UNITED BANK FOR AFRICA LTD

\begin{tabular}{ccc}
\hline Questionnaire & $\begin{array}{c}\text { Number } \\
\text { Qdministered }\end{array}$ & $\begin{array}{c}\text { \% of Questionnaire not } \\
\text { Returned }\end{array}$ \\
\hline $\begin{array}{c}\text { Number of } \\
\text { Questionnaire Returned } \\
\text { Questionnaire not } \\
\text { Returned } \\
\text { Total }\end{array}$ & 57 & 95.00 \\
\hline
\end{tabular}

Source: Field Survey, 2020.

TABLE V: SUMMARY OF QUESTIONNAIRE ADMINISTERED AND RETURNED FROM ACCESS BANK PLC

\begin{tabular}{ccc}
\hline $\begin{array}{c}\text { Questionnaire } \\
\text { Administered }\end{array}$ & $\begin{array}{c}\text { Number } \\
\text { Questionnaire }\end{array}$ & $\begin{array}{c}\text { \% of Questionnaire not } \\
\text { Returned }\end{array}$ \\
\hline $\begin{array}{c}\text { Number of } \\
\text { Questionnaire Returned }\end{array}$ & 50 & 83.33 \\
$\begin{array}{c}\text { Questionnaire not } \\
\text { Returned } \\
\text { Total }\end{array}$ & 10 & 16.67 \\
\hline
\end{tabular}

Source: Field Survey, 2020.

The data obtained were subjected to Cronbach's Alpha Coefficient reliability test. The result indicated alpha value of .900 which is above the satisfactory level. Since the result satisfied the above condition at $60 \%$ level of alpha coefficient, it can be interpreted that the instruments were reliable.

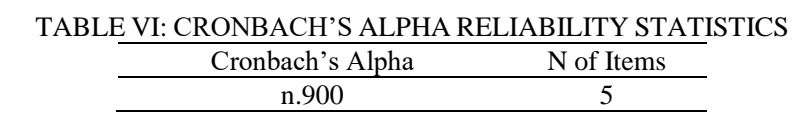

Source: SPSS Version 21.

\section{RESULT}

The data presentation and description were guided by the researchers question which were first stated after which data were analyzed appropriately.

\section{A. Analysis of Research Question}

* What is the level of the relationship that exists between electronic banking and customer satisfaction in selected Commercial Banks in Imo State (Keystone Bank Ltd, United Bank for Africa Plc and Access Bank Plc)?

For the aim of this study, electronic banking represents the independent variable and proxy for ATM, Mobile Banking and POS while customer satisfaction represents the dependent variable.

This section highlights respondent response on research question one using five-point likert scales.

Instruction: Please tick $(\sqrt{ })$ response according to your own opinion using; Strongly Agree $(\mathrm{SA}=5)$, Agree $(\mathrm{AG}=4)$, Neutral $(\mathrm{N}=3)$, Disagree $(\mathrm{DA}=2)$; Strongly Disagree $(\mathrm{SD}=1)$.

Appendix 1 shows investigative questionnaire on electronic banking and customer satisfaction.

\section{B. Test of Hypothesis}

Ho1: There is no significant relationship between automated teller machine (ATMs) and customer satisfaction.

$\mathrm{Ho}_{2}$ : There is no significant relationship between point of sale (POS) and customer satisfaction.

Hoz: There is no significant relationship between mobile banking and customer satisfaction.

\section{Decision Rule}

Reject the null hypothesis $\left(\mathrm{H}_{\mathrm{o}}\right.$ when $\mathrm{p}$-value is less $\leq 0.05$; otherwise accept alternative hypothesis.

\section{Discussion of Result}

The Table VIII below revealed the result of Pearson Moment Correlation. The result shows that there is a positive significant relationship between electronic banking and customer satisfaction in United Bank for Africa Ltd. The result shows the following value $(\mathrm{R}=.052,-.314,-.153, \mathrm{~N}=$ $65, \mathrm{P}=.002, .019, .009)$. Since the $\mathrm{P}$-value is less than 0.05 , the null $\left(\mathrm{H}_{\mathrm{ol}}\right)$ hypothesis was rejected and the alternative was accepted which states that there is level of significant between ATM, POS and Mobile Banking and customer satisfaction in United Bank for Africa Ltd.

TABLE VII: PEARSON PRODUCT CORRELATIONS

\begin{tabular}{|c|c|c|c|c|c|}
\hline & & $\mathrm{CS}$ & ATM & POS & $\mathrm{MB}$ \\
\hline \multirow{3}{*}{ CS } & Pearson Correlation & 1 & .052 & $-.314^{*}$ & -.153 \\
\hline & Sig. (2-tailed) & & .002 & .019 & .009 \\
\hline & $\mathrm{N}$ & 56 & 56 & 56 & 56 \\
\hline \multirow{3}{*}{ ATM } & Pearson Correlation & .052 & 1 & -.078 & -.007 \\
\hline & Sig. (2-tailed) & .002 & & .566 & .961 \\
\hline & $\mathrm{N}$ & 56 & 56 & 56 & 56 \\
\hline \multirow{3}{*}{ POS } & Pearson Correlation & $-.314^{*}$ & -.078 & 1 & .210 \\
\hline & Sig. (2-tailed) & .019 & .566 & & .120 \\
\hline & $\mathrm{N}$ & 56 & 56 & 56 & 56 \\
\hline \multirow{3}{*}{ MB } & Pearson Correlation & -.153 & -.007 & .210 & 1 \\
\hline & Sig. (2-tailed) & .009 & .961 & .120 & \\
\hline & $\mathrm{N}$ & 56 & 56 & 56 & 56 \\
\hline
\end{tabular}

Source: SPSS Version 21

**. Correlation is significant at the 0.01 level (2-tailed).

$\mathrm{ATM}=$ Automated Teller Machine.

POS = Point of Sale.

$\mathrm{MB}=$ Mobile Banking.

$\mathrm{CS}=$ Customer Satisfaction

The Table VIII below revealed the result of Pearson Moment Correlation. The result shows that there is a positive significant relationship between electronic banking and customer satisfaction in Access Bank Plc. The result shows the following values $(\mathrm{R}=-0.63,-.244,-.221, \mathrm{~N}=49, \mathrm{P}=.005$, $.092, .006)$. Since the P-value is less than 0.05 , the null $\left(\mathrm{H}_{01}\right)$ hypothesis was rejected and the alternative was accepted which states that there is level of significant between ATM and Mobile Banking and customer satisfaction while POS was not significant in Access Bank Plc.

TABLE VIII: PEARSON PRODUCT CORRELATIONS

\begin{tabular}{cccccc}
\hline & & CS & ATM & POS & MB \\
\hline \multirow{3}{*}{ CS } & Pearson Correlation & 1 & -.063 & -.244 & -.221 \\
& Sig. (2-tailed) & & .005 & .092 & .006 \\
& N & 49 & 49 & 49 & 49 \\
& Pearson Correlation & -.063 & 1 & .066 & -.105 \\
ATM & Sig. (2-tailed) & .005 & & .652 & .471 \\
& N & 49 & 49 & 49 & 49 \\
\multirow{4}{*}{ POS } & Pearson Correlation & -.244 & .066 & 1 & $-.318^{*}$ \\
& Sig. (2-tailed) & .092 & .652 & & .026 \\
& N & 49 & 49 & 49 & 49 \\
\multirow{3}{*}{ MB } & Pearson Correlation & -.221 & -.105 & $-.318^{*}$ & 1 \\
& Sig. (2-tailed) & .006 & .471 & .026 & \\
& $\mathrm{~N}$ & 49 & 49 & 49 & 49 \\
\hline
\end{tabular}

Source: SPSS Version 21.

**. Correlation is significant at the 0.01 level (2-tailed).

ATM $=$ Automated Teller Machine.

POS = Point of Sale.

$\mathrm{MB}=$ Mobile Banking.

$\mathrm{CS}=$ Customer Satisfaction. 
The Table IXbelow revealed the result of Pearson Moment Correlation. The result shows that there is a positive significant relationship between electronic banking and customer satisfaction in Keystone Bank Ltd. The result shows the following values $(\mathrm{R}=.319,-.206,-.053, \mathrm{~N}=54, \mathrm{P}=.019$, $.135, .003)$. Since the P-value is less than 0.05 , the null $\left(\mathrm{H}_{\mathrm{ol}}\right)$ hypothesis was rejected and the alternative was accepted which states that there is level of significant between ATM and Mobile Banking and customer satisfaction while POS was not significant in Keystone Bank Ltd.

\begin{tabular}{cccccc}
\multicolumn{6}{c}{ TABLE IX: PEARSON PRODUCT CORRELATIONS } \\
\hline \multirow{4}{*}{ CS } & CS & ATM & POS & MB \\
\hline \multirow{4}{*}{ ATM } & Pearson Correlation & 1 & $.319^{*}$ & .206 & -.053 \\
& Sig. (2-tailed) & & .019 & .135 & .003 \\
& N & 54 & 54 & 54 & 54 \\
& Pearson Correlation & $.319^{*}$ & 1 & $.517^{* *}$ & $.402^{* *}$ \\
& Sig. (2-tailed) & .019 & & .000 & .003 \\
POS & N & 54 & 54 & 54 & 54 \\
& Pearson Correlation & .206 & $.517^{* *}$ & 1 & $.305^{*}$ \\
& & .135 & .000 & & .025 \\
MB & N & 54 & 54 & 54 & 54 \\
& Pearson Correlation & -.053 & $.402^{* *}$ & $.305^{*}$ & 1 \\
& Sig. (2-tailed) & .003 & .003 & .025 & \\
& N & 54 & 54 & 54 & 54
\end{tabular}

Source: SPSS Version 21.

**. Correlation is significant at the 0.01 level (2-tailed).

ATM = Automated Teller Machine.

POS = Point of Sale.

$\mathrm{MB}=$ Mobile Banking

$\mathrm{CS}=$ Customer Satisfaction.

From the findings of the research work which states the impact of electronic banking on customer satisfaction (a study of some selected commercial banks in Imo State). The study revealed that there is a positive relationship between electronic banking and customer satisfaction of United Bank for Africa Plc., Access Bank Plc. and Keystone Bank Ltd which is used as a case study; this implies more efficient use of electronic banking system in financial sectors will not only increase customer satisfaction, it will also motivate the end user which are the customers to embrace technological ways of banking. Also, the study revealed that there is a positive relationship between Automated Teller Machine (ATM) and customer satisfaction in the three (3) banks. This implies that establishment of Automated Teller Machine has increased the satisfaction customer derives from banking system by getting quick access to Cash at all time. Also the study also revealed that there is a negative relationship between Point of Sale (POS) and customers satisfaction in Access Bank Plc. and Keystone Bank Ltd while United Bank for Africa Plc. shows a positive relationship; this could be as a result of charges levied on customers when using point of sale system in turns create dissatisfaction among the customers. Also, the study revealed a positive relationship between mobile banking and customer satisfaction in the three (3) banks; this could be as a result of efficiency in the use of mobile technology in carry out banking operation.

\section{CONCLUSION AND RECOMMENDATIONS}

\section{A. Conclusion}

It is worthy to note without doubt that greater part of the institutions including the financial sectors (banks) have to a greater extent taken the advantage of information technology(IT) to enhance their operations and customer services. Today, majority of banks have software application and website on the Internet in order to broaden their services nationwide, making available executive, reliable and standard services and promoting sophisticated service delivery. Driven by the mindset aspirations to take over the African financial services landscape and under the leadership of a dynamic and visionary management team through information technology, Nigerian banks have been continuously transformed from being just a bank to a pioneer financial solutions provider. The result is in conformity with the findings of [15], which revealed that utilization of electronic banking products is (ATM $(98 \%)$, internet banking (85\%), and electronic transfer (97\%). Constraints experienced include internet network failure, bank fraud and business loss due to failed e-transactions. Nevertheless, customers were satisfied with e-banking due to its cashless nature, cash accessibility, timesaving, and seamless transactions.

\section{B. Recommendations}

Sequel to the findings of this study, the study specifically made the following recommendations:

1. It is advised that banks should improve continuously in the advance of Automated Teller Machine for speedy transaction when using by customers.

2. Financial institutions (banks) and non-financial institutions should endeavor to make available POS machine at a minimal cost to some small business outlets in order to help in the achievement of cashless economy.

3. The banks should ensure that there is creation of more internet security in internet and mobile banking so as to avoid loss of cash by customers as a result of fraudulent activities.

4. Continuous advancement and re-engineering information communication technology should play a vital role in the overall synergy of financial institution operations (banking). It becomes more important for bank leadership to deepen investment in ICT products to increase speed, user friendly and perfect services. These will make Nigerian banks to stand firm in terms of efficiency, profitability, reliability and competitiveness among its global competitors and to withstand challenges and changes that may occur in ICT controlled globalized economy.

\section{APPENDIX}

\section{Questionnaire}

Instruction: please kindly fill in the following questions by ticking () in column of your choice.

A. Section A

Personal Data:

1) Sex: a) Male [ ]b) Female [] 
2) Age Group: (a) 18 - 25 [ ] (b) 26 - 45 [ ] (c) 46 - 55 [ ] (d) 56 and Above [ ]

3) Marital Status: (a) Married [ ] (b) Single [ ] (c) Separated [ ] (d) Divorced [ ]

4) What is your highest educational qualification? (a)

SSCE/GCE [ ]

(b) HND/First Degree [ ] (c) Masters/PhD [ ] (d) Others (Please Specify)

5) How long have you been operating with your bank? (a)

Less than two years [ ]

(b) Between two to five years [ ] (c) More than five years [ ]

6) What is your occupation? (a) Trader/private [ ] (b) Civil/public Servant [ ] (c) Others [ ]

\section{B. Section $B$}

\begin{tabular}{|c|l|l|l|l|l|l|}
\hline & \multicolumn{1}{|c|}{ Customer satisfaction } & SD & D & N & A & SA \\
\hline 1. & $\begin{array}{l}\text { Electronic banking is more } \\
\text { convenient than manual banking }\end{array}$ & & & & & \\
\hline 2. & $\begin{array}{l}\text { I am well satisfied with the services } \\
\text { my bank delivered to me. }\end{array}$ & & & & & \\
\hline 3. & $\begin{array}{l}\text { Electronic banking is safer than } \\
\text { manual banking }\end{array}$ & & & & & \\
\hline 4. & $\begin{array}{l}\text { I would like to remain as a customer } \\
\text { to my bank. }\end{array}$ & & & & & \\
\hline 5. & $\begin{array}{l}\text { I am well attended to, each time I } \\
\text { have complain }\end{array}$ & & & & \\
\hline
\end{tabular}

\begin{tabular}{|c|l|l|l|l|l|l|}
\hline & \multicolumn{1}{|c|}{ Automated Teller Machine } & SD & D & N & A & SA \\
\hline 1. & $\begin{array}{l}\text { Utility of ATM's has gain } \\
\text { worldwide popularity. }\end{array}$ & & & & & \\
\hline 2. & $\begin{array}{l}\text { Withdrawal of cash with ATM is } \\
\text { more convenient than over the } \\
\text { counter withdrawal. }\end{array}$ & & & & & \\
\hline 3. & $\begin{array}{l}\text { The reduction of cost in the off-time } \\
\text { and off-store services is quite } \\
\text { encouraging. }\end{array}$ & & & & & \\
\hline 4. & $\begin{array}{l}\text { ATM banking service is better than } \\
\text { other electronic banking service. }\end{array}$ & & & & & \\
\hline 5. & ATM dispenses money accurately & & & & & \\
\hline
\end{tabular}

\begin{tabular}{|c|l|l|l|l|l|l|}
\hline & \multicolumn{1}{|c|}{ Point of sale } & SD & D & N & A & SA \\
\hline 1. & $\begin{array}{l}\text { I am completely satisfied with the } \\
\text { service of POS transactions. }\end{array}$ & & & & & \\
\hline 2. & $\begin{array}{l}\text { My experiences with POS are really } \\
\text { encouraging. }\end{array}$ & & & & & \\
\hline 3. & $\begin{array}{l}\text { POS services cost less than other } \\
\text { electronic banking }\end{array}$ & & & & & \\
\hline 4. & $\begin{array}{l}\text { POS banking service is more } \\
\text { convenient than other electronic } \\
\text { banking service. }\end{array}$ & & & & & \\
\hline 5 & $\begin{array}{l}\text { POS banking services charge me } \\
\text { less fees }\end{array}$ & & & & & \\
\hline
\end{tabular}

\begin{tabular}{|c|l|c|c|c|c|c|}
\hline & Mobile banking system & SD & D & N & A & SA \\
\hline 1. & $\begin{array}{l}\text { Mobile banking service is more } \\
\text { effective than other electronic } \\
\text { banking service. }\end{array}$ & & & & & \\
\hline 2. & $\begin{array}{l}\text { It is so easy to have control over my } \\
\text { finance }\end{array}$ & & & & & \\
\hline 3. & $\begin{array}{l}\text { It is more secure/risk-free than } \\
\text { online internet banking. }\end{array}$ & & & & & \\
\hline 4. & $\begin{array}{l}\text { Mobile banking is more cost } \\
\text { effective than other electronic } \\
\text { banking systems. }\end{array}$ & & & & & \\
\hline 5. & $\begin{array}{l}\text { Easy and fast in ordering for cheque } \\
\text { book using your mobile app. }\end{array}$ & & & & & \\
\hline
\end{tabular}

\section{REFERENCES}

[1] Abid, H., Noreen, U. (2006): Ready to e-bank: An exploratory research on adoption of e-banking and e-readiness among customers and commercial.

[2] Abraham, H. (2012): Challenges and Opportunities of Adapting electronic banking in Ethiopia.

[3] Adegbesan, E. (2017): E-payment transactions up 33\% to N74.9trn in 2016 CBN. Vanguard Newspaper. Retrieved 27/1/2018 from https://www.vanguardngr.com/2017/11/epayment-transactions-33-n749trn-2016-cbn/.

[4] Alhaji, A.A., Rosmaini, T., andSulaman, M.L. (2013): The Impact of Electronic Banking on Customer Service Delivery in the Malaysian Banking Industry: Using Kano's Model. International Journals' Research Journal of Social Science and Management. ISSN 2251-1571.

[5] Aliyu, A,A., Tasmin, R., and Lame S.M. (2013):Impact of Electronic Banking on Customer Service Delivery in the Malaysian Banking Industry: Using Kano's Model. The international journals, research journal of social science \& management ISSN: $2251-1571$.

[6] Asiyanbi, H.B., and Ishola, A.A. (2018):E-banking Services Impact and Customer Satisfaction in Selected Bank Branches in Ibadan Metropolis, Oyo State, Nigeria. Licensee Growing Science, Canada, Article $\cdot$ March $2018 \quad$ DOI: $\quad 10.5267 /$ j.ac.2018.03.001 https://www.researchgate.net/publication/323826477.

[7] Barnes, S. J. and B. Coritt (2013), mobile banking: "concept and potential", international journal of mobile communication, Vol. 1, No. 3:273-288.

[8] Bello, D.A. (2005):The impact of E-banking on customer satisfaction in Nigeria. University Library of Munich, Germany.

[9] Birutu (2012): A quarterly magazine of the National Bank of Ethiopia. 113: $10-20$.

[10] CBN (2011): Further Clarifications on Cash-less Lagos Project. Retrieve from: http://www.cenbank.org/cashless/ on 19th Feb. 2014.

[11] CBN, Banking and Payments System Department (2013): Extension of Cash-less Policy to Five States and FCT. An Internal Memorandum, BPS/DIR/GEN/CIR/01/015.At http://www.cbn.gov.ng/.

[12] Daniel, E. (1999): Provision of electronic banking in the UK and the Republic of Ireland. International Journal of Bank Marketing,17,72 83.https://doi.org/10.1108/02652329910258934.

DOI: 10.1177/2158244018790633 journals.sagepub.com/home/sgo.

[13] Dugeri, M. (2013): Cashless Economy in Nigeria: Issues, Challenges and Prospects.

[14] Fenuga, O.J. (2010):The Effect of Electronic Payment on Customer Service Delivery. International Journal of Economic Development Research and banks in Pakistan. Spider 31: 1-31.

[15] Haadi, B.A. and Ajibola, A.I. (2018): E-banking services impact and customer satisfaction in selected bank branches in Ibadan metropolis, Oyo state, Nigeria. Contents lists available at Growing Science Accounting homepage: www.GrowingScience.com/ac/ac.html.

[16] Hammoud, J., Bizri, R.M., and Ibrahim, E.B., (2018):The Impact of EBanking Service Quality on Customer Satisfaction: Evidence from the Lebanese Banking Sector. SAGE Open July-September 2018: 1- 12 (C) The Author(s) 2018.

[17] Hansemark O.C., Albinson M. (2004): Customer Satisfaction and Retention: The experiences of Individual Employees. Managing Service Quality 14: 4057.

[18] Isibor, A.A., Omankhanlen, A.E., Okoye, L.U., Achugamonu, B.U., Adebayo M.E., Afolabi, G.T., and Ayodeji, O.E. (2018): Impact of Electronic Banking Technology On Customers' Satisfaction And Economic Growth In Nigeria, International Journal of Civil Engineering and Technology (IJCIET) Volume 9, Issue 12, December 2018, pp. 536-544, Article ID: IJCIET_09_12_059Available online at http://www.iaeme.com/ijciet/issues.asp?JType=IJCIET\&VType=9\&ITy pe=12ISSN Print: 0976-6308 and ISSN Online: 0976-6316.

[19] Jamil H., Rima M.B., and Ibrahim E.B. (2018): The Impact of EBanking Service Quality on Customer Satisfaction: Evidence From the Lebanese Banking Sector. SAGE Open July-September 2018: 1-12 (C) The Author(s) 2018 DOI: $10.1177 / 2158244018790633$ journals.sagepub.com/home/sgo.

[20] Jenevive, O.C., and Anyanwaokoro, M. (2017): Electronic Payment Methods and Profitability of Banking Firms in Nigeria: A Panel Data Analysis. International Journal of Finance andAccounting, 6(3), 67-74.

[21] Kotler, P. (2000): Marketing Management (6th edn.), Longitudinal Assessment of customer, Prentice-Hall LaBarbera, New Jersey. 
[22] Nitsure R.R. (2003): E-banking challenges and opportunities. Economic and Political weekly 38: 5377-5381 Electronic Banking." Everyday Finance: Economics, Personal Money Management, and Entrepreneurship. . Encyclopedia.com. 4 Aug. 2019 $\langle$ https://www.encyclopedia.com>.

[23] Okeci, O. and Oruan, P. (2013): Empirical Evaluation of Customers' Use of Electronic Banking Systems in Nigeria. African Journal of Computing \& ICT, Vol. 6. No.1.

[24] Oliver R.L. (1997): Satisfaction: A Behavioral Perspective on the Consumer. McGraw Hill, New York.

[25] Olorunsegun, S. (2010): The impacts of electronic banking in Nigeria banking system. Retrieved from http://mikedugeri.wordpress.com/2013/03/21/cashless-economyin-nigeria/ on 28th Jan. 2014.

[26] Robinson T. (2000), internet banking - still not a perfect marriage", information week, 17(4) 2000, pp. $104-106$.

[27] Rogers, R.A. (1984): Introduction Strategy For New Products With Positive And Negative Word-Of-Mouth. Management Science, 30(12), 1389-1404.

[28] Simon, V.T., Thomas, A. and Senaji, R. (2016): Effect Of Electronic Banking On Customer Satisfaction In Selected Commercial Banks, Kenya. International Academic Journal of Human Resource and Business Administration | Volume 2, Issue 2, pp. 41-63.

[29] Taiwo, J.N. and Agwu, M.E. (2017): The role of e-banking on operational efficiency of banks in Nigeria. Basic Research Journal of Business Management and Accounts, 6(1), 01-10.

[30] Timothy, A.T. (2012): Electronic Banking Service and Customer Satisfaction in the Nigerian Banking Industry. International Journal of business and management tomorrow.

[31] Tiwari, R., Buse,S. (2007): The Mobile Commerce Prospects: A Strategic analysis of opportunities in the banking sector. Hamburg University Press pp:

[32] Tope, D. (2010): E-Banking Operations: The Nigerian experience. Sales \& Marketing Manager NCR (Nigeria).

[33] Worku, G., Tilahun, A., and Tafa, M.,A., (2016): The Impact of Electronic Banking on Customers 'Satisfaction in Ethiopian Banking Industry (The Case of Customers of Dashen and Wogagen Banks in Gondar City), Journal of Business \& Financial Affairs Bus Fin Aff 2016, 5:2 DOI: 10.4172/2167-0234.1000174. 